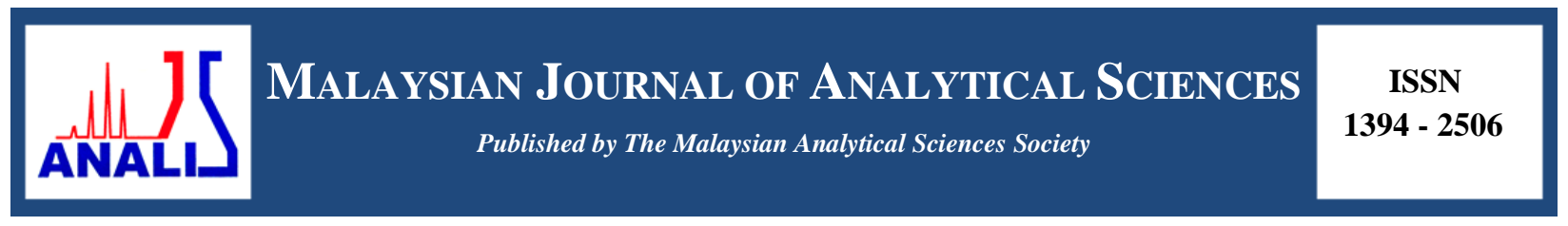

\title{
SEPARATION AND RADIOLOGICAL IMPACT ASSESSMENT OF THORIUM IN MALAYSIAN MONAZITE PROCESSING
}

\author{
(Pengasingan dan Penilaian Impak Radiologi Torium dalam Pemprosesan \\ Monazit di Malaysia) \\ Wadeeah M. Al-Areqi*, Che Nor Aniza Che Zainul Bahri, Amran Ab. Majid, Sukiman Sarmani \\ Nuclear Science Program, School of Applied Physics, \\ Faculty of Science and Technology, \\ Universiti Kebangsaan Malaysia, 43600 UKM Bangi, Selangor, Malaysia \\ *Corresponding author: walareqi@yahoo.com
}

Received: 2 November 2015; Accepted: 6 April 2016

\begin{abstract}
The processing of mineral monazite to produce thorium (Th) and rare earth elements may create a radiological impact if the processing and residue are not properly or safely managed. Malaysian Atomic Energy Licensing Board (AELB) categorized monazite as a radioactive material because the concentration of thorium in the mineral is higher than $1 \mathrm{~Bq} / \mathrm{g}$. Therefore, the current study aimed to determine the separation percentage of thorium from Malaysian monazite and to assess the radiological impact of thorium during various stages involved in the processing. In this study, monazite was digested by hot sulphuric acid followed by selective precipitation of thorium using ammonia. Neutron Activation Analysis (NAA) and Inductively Coupled Plasma Mass Spectrometry (ICP-MS) techniques were used to determine thorium. The result of the study showed that the average concentration of thorium in Malaysian monazite ore was 17,990.5 $\pm 1,239.3 \mathrm{ppm}$. After digestion, $46.56 \%$ of thorium was recovered and about $97.68 \%$ of thorium was separated as thorium hydroxide from the obtained sulphate leach solution. The study also indicated that less than $3 \%$ of Thorium entered in the rich rare earth elements filtrate during the separation. The calculated maximum dose that could be received by workers and public from the monazite ore were $61.91 \pm 4.27 \mathrm{mSv} / \mathrm{y}$ and $54.24 \pm 3.73 \mathrm{mSv} / \mathrm{y}$ respectively. However, during the processing of $25 \mathrm{~g}$ the monazite ore, the worker and public will receive a lower dose in the range of $0.01-0.72$ and $0.01-0.63 \mathrm{mSv} / \mathrm{y}$ respectively. Based on the results, useful suggestions on how to improve thorium recovery and how to minimize the radiological impact as a whole are provided.
\end{abstract}

Keywords: thorium, monazite, radiological impact, separation, dose

\begin{abstract}
Abstrak
Pemprosesan mineral monazit untuk menghasilkan torium (Th) dan unsur nadir bumi boleh menyebabkan impak radiologi sekiranya pemprosesan dan residu tidak diuruskan dengan baik. Lembaga Perlesenan Tenaga Atom Malaysia (AELB) telah mengkategorikan monazit sebagai bahan beradioaktif kerana kepekatan torium dalam mineral adalah tinggi iaitu melebihi 1Bq/g. Oleh itu, tujuan utama kajian ini adalah untuk menentukan peratus pengasingan torium daripada bijih monazit dan menilai impak radiologi torium dalam beberapa peringkat yang terlibat dalam pemprosesan. Dalam kajian ini, asid sulfurik telah digunakan untuk menghadam monazit dan diikuti dengan pemendakan terpilih torium menggunakan ammonia. Teknik Analisis Pengaktifan Neutron (NAA) dan Induktif Plasma Pendua - Spektrometri Jisim (ICP-MS) telah digunakan untuk menentukan kandungan torium. Hasil kajian menunjukkan purata kepekatan torium dalam bijih monazit Malaysia adalah 17,990.5 $\pm 1,239.3$ ppm. Selepas penghadaman, peratus mendapatkan torium adalah $46.56 \%$ dan $97.68 \%$ torium telah diasingkan sebagai torium hidroksida daripada larutan larut lesap sulfat. Kajian juga menunjukkan kurang daripada $3 \%$ torium terdapat dalam turasan unsur nadir bumi semasa pengasingan. Dos maksimum yang boleh diterima oleh pekerja dan orang awam daripada bijih monazit telah dikira dan masing - masing adalah $61.91 \pm 4.27 \mathrm{mSv} / \mathrm{y}$ dan $54.24 \pm 3.73 \mathrm{mSv} / \mathrm{y}$. Walau bagaimanapun, semasa pemprosesan bijih monazit, pekerja dan orang awam akan menerima dos yang rendah iaitu masing - masing dalam julat 0.01 -
\end{abstract}




\section{Al-Areqi et al: SEPARATION AND RADIOLOGICAL IMPACT ASSESSMENT OF THORIUM IN MALAYSIAN MONAZITE PROCESSING}

0.72 dan $0.01-0.63 \mathrm{mSv} / \mathrm{y}$. Berdasarkan hasil kajian ini, cadangan penambah baikan dalam mendapatkan torium dan bagaimana untuk meminimumkan impak radiologi secara menyeluruh dapat disediakan.

Kata kunci: torium, monazit, impak radiologi, pengasingan, dos

\section{Introduction}

Mineral processing industries containing natural radionuclides contribute to radiation exposure to the public and workers with significant doses. The radiation exposure during mineral processing industries can occur on the mining, transportation, or at any stage of mineral processing for generating the products, wastes and by-products [1]. In Malaysia, Naturally Occurring Radioactive Materials (NORM) are mainly found in scales and sludge from the oil and gas industries, iron oxide and red gypsum from the processing of ilmenite and thorium hydroxide in particular from the processing of xenotime and monazite. Other NORM are tin slag produced from the smelting of tin, ilmenite, zircon, and monazite produced from the processing of tin tailing (amang) [2,3]. These activities are regulated and controlled under the Atomic Energy Licensing Act, 1984 (Act 304).

Malaysia implemented $1 \mathrm{~Bq} / \mathrm{g}$ for naturally occurring radionuclides from ${ }^{238} \mathrm{U}$ and ${ }^{232} \mathrm{Th}$ decay series in raw material and waste as the control limit of activity concentrations. It stated the annual dose limit for the members of the public and workers from the activity concentration of radionuclides must be below the control limits which are unlikely to exceed $1 \mathrm{mSv} / \mathrm{y}$ and $20 \mathrm{mSv} / \mathrm{y}$, respectively [4,5]. There are two sources of thorium existing in Malaysia namely rare earth minerals and rare earth elements production residue. For instance, Malaysian monazite containing thorium ranged between $6.5-7.5 \%$ and the average thorium concentrations in xenotime were $1.5 \%$ [6]. The residue from Asian Rare Earth (ARE) contains $36 \%$ of thorium meanwhile Water Leach Purification (WLP) residue generating from Lynas Advanced Materials Plant (LAMP) containing $0.17 \%$ of thorium with total dose contribution of Th232, Ra-228, U-238 and Ra-226 for workers and public 3.90 and $0.20 \mathrm{mSv} / \mathrm{y}$, respectively [3, 6, 7]. Practically, the processing of monazite for rare earth production will produce a significant amount of thorium that needs to be managed safely to prevent the public concern and environmental impacts.

Typically, thorium is extracted from its minerals with either hot sulphuric acid or hot strong alkali, converted into thorium nitrate and extracted with tributyl phosphate (TBP) in kerosene for final purification of the thorium $[4,5$, 11]. Chemically, monazite is phosphate of thorium and rare earths besides small uranium content. It is particularly rich in the light REEs. Digestion of monazite mineral can be used hot concentrated sulphuric acid or hot alkali. In typical acid process, cracking monazite mineral is performed at $>230^{\circ} \mathrm{C}$ as shown in the following equation 1 :

$$
\mathrm{Th}_{3}\left(\mathrm{PO}_{4}\right)_{4}+6 \mathrm{H}_{2} \mathrm{SO}_{4} \rightarrow 3 \mathrm{Th}\left(\mathrm{SO}_{4}\right)_{2}+4 \mathrm{H}_{3} \mathrm{PO}_{4}
$$

In the acid process, thorium and REEs which are water soluble salts in monazite sulphuric solution are filtrated, and thorium is separated from these REEs by reducing the acidity to precipitate thorium as thorium hydroxide usually in the selective precipitation. Moreover, ammonia is used at about $\mathrm{pH} 1.05$. Nitric acid may dissolve thorium hydroxide precipitate. Produced thorium nitrates in acid solutions are widely used to extract thorium into organic solvents. For purification of thorium from impurities, solvent extraction commonly using tributyl phosphate TBP in kerosene is achieved by a multi-stage extracting and stripping process [10 - 14].

In strong alkali digestion, insoluble thorium hydroxide is produced in thorium cake which is easily dissolved in acid as illustrated by the following equation 2 :

$$
\mathrm{Th}_{3}\left(\mathrm{PO}_{4}\right)_{4}+12 \mathrm{NaOH} \rightarrow 3 \mathrm{Th}(\mathrm{OH})_{4}+4 \mathrm{Na}_{3} \mathrm{PO}_{4}
$$

Thorium is purified by solvent extraction in nitric acid media [14 - 16]. Pure thorium nitrate can be converted into thorium peroxide or thorium oxalates which are calcinated at $800{ }^{\circ} \mathrm{C}$ in a furnace to produce high purity thorium oxide $[17,18]$. Previous studies separated thorium from the rare earth residue and RE ores in order to minimize the environmental impact of thorium radioactivity and to produce thorium for future nuclear fuel $[3,8,9]$. 
In the present study, the separation percentage of thorium from Malaysian monazite and the improvement on thorium separation were studied. Radiological impact assessment of thorium was discussed for the whole scenario of Th separation, and it was suggested to minimize the radiological impact as well.

\section{Separation of thorium}

\section{Materials and Methods}

Malaysian monazite sample was collected from Syarikat Leong Sin Nam, Kempari, Perak and it was grinded to obtain fine powder. In preparing the samples for gamma spectrometry (HPGe), sample together with standard reference material namely (IAEA soil-375) were stored for 4 weeks in sealed plastic containers to re-establish the secular radioactive equilibrium. The specific activities of the natural radionuclides ${ }^{232} \mathrm{Th}$ and ${ }^{238} \mathrm{U}$ were measured for a period of 12 hours by HPGe $\gamma$-ray spectrometry. The ${ }^{232} \mathrm{Th}$ specific activity was determined from Ac-228 (911.1 $\mathrm{keV})$ and $\mathrm{Tl}-208(583.2 \mathrm{keV})$ respectively. In addition, the ${ }^{238} \mathrm{U}$ specific activity was assessed using Bi-214 $(1764.49 \mathrm{keV})$.

In preparing the samples for the instrumental neutron activation analysis (INAA), approximate $0.05 \mathrm{~g}$ of monazite sample and $0.4 \mathrm{~g}$ standard reference material (IAEA $312 \mathrm{~N}$ ) were placed in high-purity polyethylene irradiation vials and sealed by heat sealing process. Triplicates were prepared for each sample. Then, the samples, standard reference materials and standard solution were irradiated for 1 hour in the rotary rack (RR) facility of the TRIGA Mark II reactor at Malaysian Nuclear Agency. The measurements were carried out using a HPGe detector (GC3018) and the analysis of photo peaks were performed using Genie-2000 software (Canberra Inc.).The samples were measured for 1 hour at different cooling times which ranged from 2 days to 4 weeks and measured at $4 \mathrm{~cm}$ distances from the detector.

\section{Monazite leach sulphuric acid solution}

The digestion of monazite and the selective precipitations of thorium were performed on glass beakers and the measurements of $\mathrm{pH}$ were carried out using EUTECH instruments $\mathrm{pH} 700$. The thorium concentrations in the aqueous solutions were determined using ICP-MS -ELAN 9000 (PerkinElmer SCIEX). There are two main parts of the process: Digestion of monazite with hot sulphuric acid and dissolving with water to produce monazite leach sulphate solution and separation of thorium from REEs and $U$ by selective precipitation using ammonia and produce thorium precipitate as shown in Figure 1.

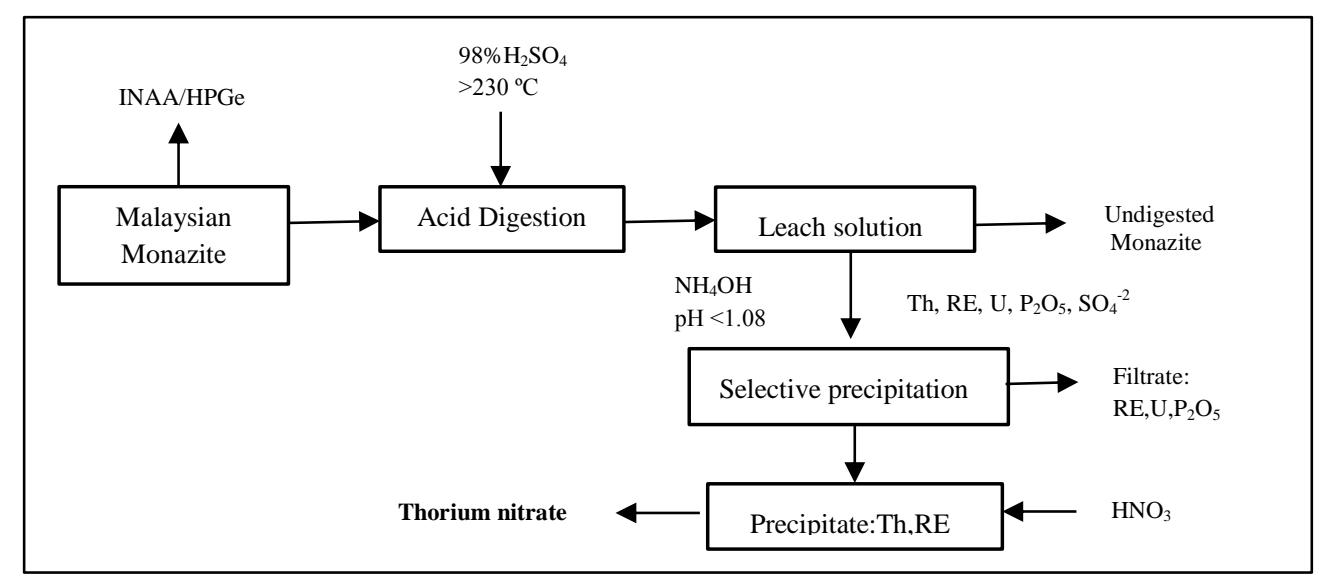

Figure 1. Simplified flowchart for sulphuric acid digestion of Malaysian monazite and recovery of thorium

\section{Digestion of Malaysian monazite}

The monazite leach solution used in this study was prepared by digesting approximately $25 \mathrm{~g}$ of monazite in $75 \mathrm{ml}$ of $98 \%$ sulphuric acid at $200{ }^{\circ} \mathrm{C}$ for 3 hours as digestion time using the glass beakers on the stirring hot plate. Then, 


\section{Al-Areqi et al: SEPARATION AND RADIOLOGICAL IMPACT ASSESSMENT OF THORIUM IN MALAYSIAN MONAZITE PROCESSING}

the mixture was cooled to room temperature, adding $200 \mathrm{~mL}$ water to dissolve the metal sulphates, and filtering to produce a clear solution.

\section{Selective precipitation of thorium with ammonia}

The monazite leach solution contains thorium, rare earths, and uranium with other impurities. Reduction of the acidity of sulphate leach solution at a $\mathrm{pH}$ of 1: 05 can precipitate thorium and leave the rare earths and uranium in the solution [10,14]. In this part, $100 \mathrm{~mL}$ of leach solution was used and the selective precipitation for thorium was carried out at $\mathrm{pH} 1.08-1.89$ using ammonia. The thorium rich precipitate was filtrated and dissolved in nitric acid to form thorium concentrate solution. ICP-MS used for determination of metal concentrations in the monazite leach solution, thorium concentrate and RE filtrate solutions. Triplicate procedures were performed and separation percentage of thorium from monazite leach solution was calculated.

\section{Radiological impact assessment}

Thorium concentrations were determined in Malaysian monazite ore and in each stage of the chemical process to produce the thorium nitrate. Radiological impact was assessed based on the magnitude of radiation hazard and effective dose rates. All the data on the activity concentrations of thorium in each stage of process was obtained from converting the thorium concentration into $\mathrm{ppm}$ to $\mathrm{Bq} / \mathrm{g}$. The Annual Effective Doses Equivalent for public and workers were estimated using equation (3) as recommended by UNSCEAR 2000 [19].

$$
\begin{aligned}
\text { Annual Effective Dose Equivalent }(\mathrm{mSv} / \mathrm{y})= & \text { Dose rate at } 1 \mathrm{~m}(\mathrm{nGy} / \mathrm{h}) \times \text { time }(\mathrm{h} / \mathrm{y}) \times \text { occupancy factor } \\
& \times \text { conversion factor }(\mathrm{Sv} / \mathrm{Gy}) \times 10^{-6}
\end{aligned}
$$

where Dose rate is define as activity of $\mathrm{Th}(\mathrm{Bq} / \mathrm{kg}) \mathrm{x}$ conversion factor for Th $\left(0.604 \mathrm{nGyh}^{-1} / \mathrm{Bqkg}^{-1}\right)$, Time for public is define as 365 days $\mathrm{x} 24$ hours $=8760$ hours and working time for worker is define as 2000 hours. Occupancy factor for outdoor activity is 0.2 and conversion factor is $0.7 \mathrm{~Sv} / \mathrm{Gy}$.

\section{Results and Discussion}

Thorium and uranium in Malaysian monazite were determined via the NAA and gamma ray spectroscopy. The mean concentrations of thorium and uranium in Malaysian monazite are presented in Table 1 . The activity concentrations of thorium and uranium were $15258.14 \pm 28.71 \mathrm{ppm}(62.41 \pm 0.05 \mathrm{~Bq} / \mathrm{g})$ and $1445.68 \pm 19.38 \mathrm{ppm}$ $(17.98 \pm 0.24 \mathrm{~Bq} / \mathrm{g})$ respectively by gamma spectroscopy. Mean concentrations of thorium and uranium via the NAA were 17,990.52 $\pm 1,239.3 \mathrm{ppm}(73.58 \pm 5.07 \mathrm{~Bq} / \mathrm{g})$ and $637.29 \pm 25.8(2.61 \pm 0.11 \mathrm{~Bq} / \mathrm{g}) \mathrm{ppm}$, respectively. In addition, the relative error of the INAA for analysis of ${ }^{232} \mathrm{Th}$ and ${ }^{238} \mathrm{U}$ in IAEA $312 \mathrm{~N}$ was determined and they were calculated as $4.59 \%$ and $9.64 \%$, respectively. Because the concentration of thorium obtained from NAA was more accurate, it was used for the following calculations of the thorium separation and radiological impact assessment. The study indicated that the different results between these two techniques could be due to radioactive equilibrium, homogeneity problems or gamma rays interferences.

Table 1. Mean concentration of thorium and uranium (ppm) measured in Malaysian Monazite by NAA and Gamma ray spectroscopy

\begin{tabular}{lccccc}
\hline \multirow{2}{*}{ Element } & \multicolumn{2}{c}{ NAA } & \multicolumn{2}{c}{$\gamma$ - ray spectroscopy } & AELB* \\
\cline { 2 - 6 } & $\mathbf{p p m}$ & $\mathbf{B q} / \mathbf{g}$ & $\mathbf{p p m}$ & $\mathbf{B q} / \mathbf{g}$ & $\mathbf{B q} / \mathbf{g}$ \\
\hline Th-232 & $17,990.52 \pm 1,239.3$ & $73.58 \pm 5.07$ & $15258.14 \pm 28.71$ & $62.41 \pm 0.05$ & 1 \\
U-238 & $637.29 \pm 25.8$ & $2.61 \pm 0.11$ & $1445.68 \pm 19.38$ & $17.98 \pm 0.24$ & 1 \\
\hline
\end{tabular}

*The limit control is imposed by Atomic Energy Licensing Board

As seen from the results presented in Table 1, Malaysian monazite ore was rich with thorium compared to uranium. Moreover, the thorium concentration was much higher than the AELB control limit, and therefore, Malaysian monazite was classified as the radioactive mineral. The low level of uranium in Malaysian monazite does not cause 
serious radiological hazard into the environment and public while thorium has a great concern due to its high level concentrations of ore and residue.

\section{Separation of thorium}

The study on digestion of Malaysian monazite showed that it could be achieved about $46.56 \%$ of thorium recovery under the previously mentioned parameters and significant amount of thorium was left in the undigested monazite residue. Thorium recovery can be improved if the multi-stage digestion process is required. As a result of this, thorium will decrease in the residue and then reduce the hazard of radioactivity too. At high temperature $\left(<230{ }^{\circ} \mathrm{C}\right)$ used in chemical digestion processing, the thorium is converted into refractory and insoluble form (thorium pyrophosphate) and subsequently removed it completely from the residue $[8,20-22]$. In this study, the temperature was used less than $230{ }^{\circ} \mathrm{C}$ to avoid forming insoluble thorium form. Table 2 shows thorium separation from sulphate leach solution and thorium recovery from Malaysian monazite.

Table 2. Thorium separation from sulphuric leach solution ( $\mathrm{pH} 1.08-1.84$ by $13.4 \mathrm{M} \mathrm{NH}_{4} \mathrm{OH}$ )

\begin{tabular}{lccc}
\hline $\begin{array}{l}\text { Stage of Chemical } \\
\text { Extraction Process }\end{array}$ & $\begin{array}{c}\text { Th Concentration } \\
(\mathbf{p p m})\end{array}$ & $\begin{array}{c}\text { Th Recovery* } \\
(\mathbf{\%})\end{array}$ & $\begin{array}{c}\text { Th Separation } \\
(\mathbf{\%})\end{array}$ \\
\hline Monazite ore by NAA & $17,990.52 \pm 1,239.3$ & & \\
Sulphuric leach solution & $837.61 \pm 11.7$ & 46.56 & \\
Selective precipitation & & & \\
Sulphuric leach solution in $100 \mathrm{~mL}$ & $837.61 \pm 11.7$ & & \\
Thorium precipitate & $260.10 \pm 0.10$ & & 97.68 \\
Rich- RE filtrate & $7.76 \pm 2.93$ & & \\
\hline
\end{tabular}

*Thorium recovery percentage was calculated using $25 \mathrm{~g}$ of Malaysian monazite

The results of this separation showed that most of thorium was separated from the monazite sulphate solution by selective precipitation at $\mathrm{pH} 1.08-1.84$ using ammonia. The percentage of the thorium separation obtained in this study was almost $97.68 \%$ and only less than $3 \%$ of total thorium was left in the rich rare earth filtrate as shown in Table 2. Furthermore, the different $\mathrm{pH}$ and concentration of ammonia as a precipitant were affected the separation percentage results. The obtained thorium precipitate contained only a small amount of rare earth elements which was co-precipitated during the reduction of the acidity. Subsequent purification of thorium precipitated by solvent extraction is required to extract the thorium nitrate from rare-earth elements and other impurities.

\section{Radiological impact assessment}

Based on the high concentration of thorium in the Malaysian monazite ore samples (17,990.52 $\pm 1,239.3 \mathrm{ppm})$, the risk assessment performed indicates the thorium was responsible for the high risk. The average annual effective doses equivalent received by workers and public from Malaysian monazite were calculated to be $61.91 \pm 4.27$ $\mathrm{mSv} / \mathrm{y}$ and $54.24 \pm 3.73 \mathrm{mSv} / \mathrm{y}$, respectively. These values are over 3 times for workers and 54 times for public of the annual dose limit.

Table 3 shows the annual effective dose equivalent for public and workers during the processing of $25 \mathrm{~g}$ Malaysian monazite. As previously mentioned the radiological risk of Th in each step of the monazite processing depends on distribution of thorium during the processing, whatever the purpose of separation is and whether separating thorium as a product or removing it from the residue in order to produce REEs. From Table 3, it is apparent that the annual effective doses equivalent received by public and worker resulting from $25 \mathrm{~g}$ of monazite ore were 1.36 and 1.56 $\mathrm{mSv} / \mathrm{y}$, respectively. The dose for public was higher than AELB requirement. 


\section{Al-Areqi et al: SEPARATION AND RADIOLOGICAL IMPACT ASSESSMENT OF THORIUM IN MALAYSIAN MONAZITE PROCESSING}

Table 3. Annual Effective Dose Equivalent for public and workers (mSv/y) during the processing of (25 g)

Malaysian monazite

\begin{tabular}{lcccc}
\hline Stage of Process & $\begin{array}{c}\text { Total } \\
\text { content of } \\
\text { Th }(\mathbf{m g})\end{array}$ & $\begin{array}{c}\text { Activity of } \\
\text { Th }(\mathbf{B q})\end{array}$ & $\begin{array}{c}\text { Annual Effective Dose } \\
\text { Equivalent for public } \\
(\mathbf{m S v} / \mathbf{y})\end{array}$ & $\begin{array}{c}\text { Annual Effective Dose } \\
\text { Equivalent for worker } \\
(\mathbf{m S v} / \mathbf{y})\end{array}$ \\
\hline Monazite ore $(25 \mathrm{~g})$ & 449.76 & 1839.53 & 1.36 & 1.56 \\
Sulphuric leach solution & 209.40 & 856.46 & 0.63 & 0.72 \\
$(250 \mathrm{~mL})$ & & & & \\
Undigested monazite (residue) & 240.36 & 983.07 & 0.73 & 0.83 \\
Sulphuric leach solution in & 83.76 & 342.58 & 0.25 & 0.29 \\
100 mL & & & & \\
Thorium precipitate & 26.01 & 106.38 & 0.08 & 0.09 \\
Rich- RE filtrate & 1.94 & 7.93 & 0.01 & 0.01 \\
\hline
\end{tabular}

The results also show that single - stage digestion process decreased the dose to be become the half of the initial raw monazite. Several process stages are required for achieving the minimal thorium in the residue as well as improvement of the experiment parameters.

Undigested monazite residue may cause slightly radiological risk with the annual effective dose equivalent for public 0.73 and $0.83 \mathrm{~m} \mathrm{~Sv} / \mathrm{y}$ for workers, therefore, it is required to manage safely especially whenever using large amount of monazite. However, during the processing of the monazite ore, the worker and public received lower dose in the range $0.72-0.01$ and $0.63-0.01 \mathrm{mSv} / \mathrm{y}$ respectively. It may be seen that the radiological risk in the final stages was much less than the recommended value because thorium content was completely separated during the process.

From this scenario, it was indicated that the radiological risk decreases from the initial until the final process if the separation of thorium is well performed and safely managed. Moreover, comparing the radiological impact assessment of our study with LAMP, it can be seen that LAMP reported that maximum dose rates received by workers and pubic resulting from operation of the plant were $5.61 \mathrm{mSv} / \mathrm{y}$ and $0.002 \mathrm{mSv} / \mathrm{y}$, respectively. These doses are below AELB requirement and those reported in our study. The present study showed that Malaysian monazite processing caused a significant radiological impact on workers and public.

\section{Conclusion}

The results of the current study showed that it was possible to achieve about $46.56 \%$ of thorium recovery by signal stage digesting monazite with hot sulphuric acid and separation percentage of thorium from REEs in monazite leach solution was $97.68 \%$ using selective precipitation by ammonia. The optimum parameters of separation were stated. It can be figured out that most of thorium was separated during ammonia precipitation and co-precipitated few amount of REEs. Improvement of the separation was required for several flows. The calculated maximum doses that could be received by workers are $61.91 \pm 4.27 \mathrm{mSv} / \mathrm{y}$ and public $54.24 \pm 3.73 \mathrm{mSv} / \mathrm{y}$ from the Malaysian monazite ore which were high than the control limits. However, the lower dose in the range of $0.01-0.72$ and $0.01-0.63$ $\mathrm{mSv} / \mathrm{y}$ respectively was received by the worker and public during the processing of monazite. The results of the effective dose showed that a regulatory control is required to save the public and workers from these types of activities.

\section{Acknowledgement}

The authors would like to thank the grant project with reference number FRGS/2013/ST01/UKM/01/2, UKM-GUP2012-083 and FP0214D052-2.4DSTIN for sponsorship, great thank to MTCP scholarship, Malaysia Nuclear Agency and Nuclear Science Program, UKM. 


\section{References}

1. Pontedeiro, E. M., Heilbron, P. F. L and Cotta, R. M. (2007). Assessment of the mineral industry NORM/TENORM disposal in hazardous landfills. Journal of Hazardous Materials, 139: 563 - 568.

2. Omar, M. (2010). NORM processing in Malaysia: An overview nuclear Malaysia/L/2010/11.1

3. Al-Areqi, W. M, Ab. Majid, .A. and Sarmani, S. (2015). Thorium: Issues and prospects in Malaysia. AIP conference proceedings 1659: $1-7$.

4. IAEA. (2011). Radiation protection and safety of radiation sources: International basic safety standards, GSR Part 3.Access online http://www-pub.iaea.org/MTCD/publications/PDF/Pub1578_web-57265295.pdf

5. The Atomic Energy Licensing (Radioactive Waste Management) Regulations (2011). http://www.ecolex.org/details/legislation/atomic-energy-licensing-radioactive-waste-management-regulations2011-lex-faoc107766/

6. The Academy of Sciences Malaysia (2013). Revitalising of rare earth mineral programme in Peninsula Malaysia as a strategic industry, The Academy of Sciences Malaysia (ASM) study report 1/2013.

7. Radiological impact assessment (2011). Radiological impact assessment of Lynas Advanced Materials Plant 2011: Executive Summary. Access online 4 November 2011.

8. Al-Areqi, W. M, Ab. Majid, A. and Sarmani, S. (2014). Digestion study of water leach purification (WLP) residue for possibility of thorium extraction. Malaysian Journal of Analytical Sciences, 18(1): 221 - 225.

9. Al-Areqi, W. M, Ab. Majid, A. and Sarmani, S. (2014). Separation of thorium (IV) from lanthanide concentrate (LC) and water leach purification (WLP) residue. AIP conference proceedings 1614: 482.

10. Vijayalakshmi, R., Mishra, S. L., Singh, H. and Gupta, C. K. (2001). Processing of xenotime concentrate by sulphuric acid digestion and selective thorium precipitation for separation of rare earths. Hydrometallurgy, 61: $75-80$.

11. Crouse D. J. and Brown K. B. (1959). Recovery of thorium, uranium, and rare earths from monazite sulfate liquors by amine extraction (AMEX) process, USA: Oak Ridge National Laboratory, pp 5-66.

12. Wang L., Y. Yu, X. Luang, Z. Long and D. Cui. (2013). Toward greener comprehensive utilization of bastnaesite: Simultaneous recovery of cerium, fluorine, and thorium from bastnaesite leach liquor using HEH(EHP) . Chemical Engineering Journal, 215-216: 162 - 167.

13. Amaral, J.C.B.S. and Morais, C. A. (2010).Thorium and uranium extraction from rare earth elements in monazite sulphuric acid liquor through solvent extraction. Minerals Engineering, 23:498 - 503.

14. Wickleder, M. S. Fourest, B. and Dorhout, P. K. (2010). The chemistry of the actinide and transactinide Elements, Chapter three: Thorium pp 52.

15. Ali, A. M. I, El-Nadi, Y. A, Daoud, J. A. and Aly, H. F. (2007). Recovery of thorium (IV) from leached monazite solutionsusing counter-current extraction. International Journal of Mineral Processing, 8: 217 - 223.

16. Hughes, K. C. and Singh, R. (1980). The isolation of thorium from monazite by solvent extraction. Hydrometallurgy, 6: $25-33$.

17. Balakrishna, P., Varma, B. P., Krishnan, T. S., Mohan, T. R. R. and Ramakrishnan, P. (1988). Thorium oxide: calcination, compaction and sintering. Journal of Nuclear Materials, 160: 88 - 94.

18. Abrao, A., Alves de Freitas, A. and Sequeira de Carvalho, F. M. (2001). Preparation of highly pure thorium nitrate via thorium sulfate and thorium peroxide. Journal of Alloys and Compounds, 323-324: 53 - 56.

19. UNSCEAR (2000). Sources and effects of ionizing radiation. united nations scientific committee on the effects of atomic radiation. Report to the general assembly with annexes. United Nations Publication, New York.

20. IAEA (2011). Radiation protection and NORM residue management in the production of rare earths from thorium containing minerals, Safety reports series No. 68.

21. Cardarelli, F. (2008). Materials Handbook: A Concise Desktop Reference, $2^{\text {nd }}$ Edition.

22. Zhu, Z., Pranolo, Y. and Cheng, C. Y. (2015). Separation of uranium and thorium from rare earths for rare earth production - A review. Minerals Engineering, 77: 185 - 196. 